\title{
Survival and growth of blue grama seedlings in competition with western wheatgrass
}

\author{
MARILYN J. SAMUEL AND RICHARD H. HART
}

Authors are former botanist and range scientist, USDA, Agricultural Research Service, 8408 Hildreth Rd., Cheyenne, Wyo. 82009. Samuel's present address is 1203 3rd Street E, Lehigh Acres, Fla. 33936.

\begin{abstract}
Competition from other plant species may inhibit establishment and reduce phytomass production of blue grama [Bouteloua gracilis (H.B.K.) Griffiths] on rangeland. Varying levels of competition were achieved by transplanting four-week-old blue grama seedlings into openings $0,4,8$, or $16 \mathrm{~cm}$ in diameter in western wheatgrass [Pascopyrum smithii(Rydb.) A. Love] sod or in fallow soil. After the first growing season, $42,79,88$, and $92 \%$ of blue grama seedlings survived in $0,4,8$, and $16 \mathrm{~cm}$ openings, respectively, in sod. All plants survived the first growing season in all treatments on fallow, but $86 \%$ of the plants in fallow died the first winter. In the first growing season, blue grama plants averaged over 13 seed heads per plant in fallow but less than 1 seed head per plant in sod. Both above- and below-ground phytomass of blue grama and western wheatgrass were reduced by competition. Plant height in fallow was about twice that in sod. Both survival and vigor of blue grama seedlings were reduced with increasing levels of western wheatgrass competition. For successful establishment of blue grama in an existing sward, artificial or natural openings must be created.
\end{abstract}

Key Words: above-ground standing crop, Agropyron smithii, below-ground phytomass, Bouteloua gracilis, gap size, Pascopyrum smithii, plant competition, seedling survival

\footnotetext{
The authors thank Gary V. Richardson, USDA-ARS statistician, Fort Collins, Colo., for statistical analyses.

Manuscript accepted 26 Dec. 1991.
}

Blue grama [Bouteloua gracilis (H.B.K.) Griffiths] is the dominant grass species over much of the Central Great Plains, but re-establishment following destruction by cultivation or grazing is siow and uncertain (Riegel 1941, Hyder et al. 1975). Tomanek et al. (1955) reported that blue grama provided only $11 \%$ of the herbage production on a field abandoned for 33 years, vs. $27 \%$ on native rangeland. Distinct plowlines, 40 and 50 years old, are visible because blue grama on the plowed site has not returned to the preplowing population (Hyder et al. 1975, Samuel 1985). Costello (1944) suggested the mixed prairie association may be apparent after 20-25 years of succession under exceptionally favorable conditions, but frequently was not well advanced before 40 to 50 years.

Establishment failures occur in seeded blue grama as well as in natural stands. Hyder et al. (1971) reviewed several failures and only 1 success, an area where seeded rows were covered with a thin asphalt mulch (Bement et al. 1961).

The seedling morphology of blue grama contributes to its slow reestablishment. Blue grama needs moist, warm soil during germination and again several weeks later for development of the permanent adventitious root system (Wilson and Briske 1979). The adventitious roots emerge within several millimeters of the soil surface. In many years adequate moisture may not be available in this shallow layer.

A second factor limiting blue grama establishment may be competition from established species. Sousa (1984) concluded that spatial and temporal variation in the density of "safe sites", as well as the availability of propagules, limits rates of establishment of 
many plants. Fenner (1978) found that 11 of 12 plant species germinated as well in $2.5-\mathrm{cm}$ gaps in short turf as in bare soil. However, dry weight of shoots was greatly reduced in turf in 10 of 12 species. McConnaughay and Bazzaz (1987) found that few seedlings of 7 annual weed species survived in undisturbed $P o a$ pratensis sod; optimum gap size for survival varied among species; and biomass per plant increased with increasing gap size (up to 40 $\mathrm{cm}$ ) for all species. Peart (1989 b and c) found that establishment of Anthoxanthum odoratum and Holcus lanatus in California grassland was increased 6-to 2,500-fold in canopy gaps created by death of mature plants and 10-to 200-fold on gopher mounds over that in undisturbed vegetation. Deschampsia holciformis and Rytidosperma pilosum established poorly on all sites.

The objective of this study was to measure the effect of intensities of competition by western wheatgrass on the survival and growth of germinated blue grama seedlings. Response of western wheatgrass was also measured.

\section{Methods and Materials}

The study site was a dryland plot area of the High Plains Grasslands Research Station northwest of Cheyenne, Wyo. The 118year average annual precipitation was $338 \mathrm{~mm}$ with $70 \%$ occurring between 1 April and 30 September. Precipitation was 138, 111, and $146 \%$ of normal for the 3 years of the study (N.O.A.A. 1986-1988).

'Hachita' blue grama seed were germinated on filter paper and, on 1 May 1985 , singly transplanted into $2.5-\mathrm{cm}$ diameter by $15.2-$ $\mathrm{cm}$ deep cells filled with Wheatridge loam. Plants were grown in a greenhouse for 4 weeks (temperature $15-30^{\circ} \mathrm{C}$, natural daylength, daily watering). Under these conditions, adventitious roots should have begun developing after about 2 weeks (Wilson and Briske 1979).

On 29 May 1985, seedlings were transplanted into western wheatgrass sod or fallow soil on a Wheatridge soil (fine loam over sand or sandy-skeletal, mixed mesic Aridic Argiustoll; Stevenson et al. 1984). The sod was 'Rosana' western wheatgrass [ Pascopyrum smithii (Rydb.) A. Love] which had been planted 5 years earlier (nomenclature of Triticeae follows Barkworth and Dewey 1985). Western wheatgrass was selected because it was commonly associated with blue grama on rangeland and it rapidly reestablishes after disturbance because of its rhizomatous growth habit. Herbage production on this stand averaged $116 \mathrm{~g} \mathrm{~m}^{-2}$ from 1981 through 1983 (unpublished data). The fallow blocks were springtooth harrowed and cultipacked before planting.

Cores or cylinders of soil 4,8 , or $16 \mathrm{~cm}$ in diameter and $30-\mathrm{cm}$ deep were removed from the western wheatgrass sod, to create gaps of about 13,50, and $210 \mathrm{~cm}^{2}$ and provide various degrees of reduced competition for the transplanted blue grama seedlings. A " 0 -cm" opening, which did not remove any competing vegetation, was made by pushing a dibblestick into the ground to make a hole large enough to insert the blue grama seedling. Although there were no plants and hence no competition, cores of the same sizes were removed from the fallow to produce similar physical disturbance.

Core sizes were chosen to include or approach some of the sizes of disturbances examined by Silvertown and Smith (1988), 1-16 $\mathrm{cm}^{2}$; Fenner (1978), $5 \mathrm{~cm}^{2}$; McConnaughay and Bazzaz (1987), 20-1257 $\mathrm{cm}^{2}$; Peart (1989c), 225 and about $450 \mathrm{~cm}^{2}$; and the dung-pats of Coffin and Lauenroth (1988), 134-190 $\mathrm{cm}^{2}$.

Blue grama transplants were placed 1 per hole and the holes were filled with soil from the fallow area. Because the soil was moist from $38 \mathrm{~mm}$ of rain in the preceding 2 weeks, no water was applied at transplanting or later.

The experimental design consisted of 4 replicate blocks in sod and in fallow. Blocks were 2.4 by $9.8 \mathrm{~m}$. Four treatment plots, 1 for each intensity of competition, were randomized within each block.
Treatment plots contained 6 blue grama plants in a row and were oriented 2 plots per row in 2 parallel rows within each block. Plants were set 70-cm apart within rows and 1-m apart between rows. Weeds were removed during the growing season in fallow.

Blue grama seedling survival was recorded approximately weekly during the first growing season and in June and September of the second and third growing seasons. Chi-square contingency tables were used to analyze differences in blue grama survival between sod and fallow the first year and between intensities of competition (opening sizes) in sod in all years. Seed heads were counted and plant height (extended leaf or stem length) was measured in late August of the first growing season.

At the end of the third growing season, above- and belowground phytomass of blue grama and western wheatgrass were determined. Blue grama plants were clipped to ground level; western wheatgrass was clipped to ground level inside a $15.2-\mathrm{cm}$ diameter frame centered on each blue grama plant. Below-ground phytomass was then estimated by removing a core $16 \mathrm{~cm}$ in diameter and 30-cm deep around each blue grama plant. Most of the roots of both species should have been found above the $30-\mathrm{cm}$ depth. Weaver (1958) found $79 \%$ of roots in the top $15 \mathrm{~cm}$; Bartos and Sims (1974) found $69 \%$ of the root and crown weight of shortgrass prairie in the top $20 \mathrm{~cm}$; and Weaver and Zink (1946) found $80 \%$ of roots in the top $35 \mathrm{~cm}$ of soil. Cores were removed from replications 1 and 3 in October 1987 and from replications 2 and 4 in April 1988. Soil was washed from the roots and the roots were separated by species. Above- and below-ground phytomass was dried and weighed.

Phytomass of blue grama is reported on a per plant basis. Phytomass of western wheatgrass is reported per frame for aboveground and per core for below-ground plant material. Phytomass and plant height data were subjected to analysis of variance, first as a randomized block design with unequal subsamples. When no significant differences among blocks were found in any measurement, data were re-analyzed with individual plants as samples. Means were separated $(P \leq 0.05)$ by Tukey's Highest Significant Difference test, modified for unequal sample numbers and, where necessary, unequal variances. Regressions of above- and belowground phytomass of both grasses on opening diameter also were calculated.

\section{Results and Disucssion}

Blue grama survival was $100 \%$ at all intensities of competition (opening sizes) in fallow after the first growing season (Table 1). Because no differences in survival were detected among opening

Table 1. Survival of blue grama seedlings planted into 4 sizes of openings in fallow soil or western wheatgrass sod.

\begin{tabular}{llcccc}
\hline \hline \multirow{2}{*}{ Planted in: } & \multirow{2}{*}{$\begin{array}{c}\text { Growing } \\
\text { season }\end{array}$} & \multicolumn{4}{c}{ Opening diameter, cm } \\
\cline { 3 - 6 } Fallow & & 0 & 4 & 8 & 16 \\
\hline \multirow{3}{*}{ Sod } & First & $100 \mathrm{a}$ & $100 \mathrm{a}$ & $100 \mathrm{a}$ & $100 \mathrm{a}$ \\
& & $*$ & $*$ & & \\
& First & $42 \mathrm{~b}$ & $79 \mathrm{a}$ & $88 \mathrm{a}$ & $92 \mathrm{a}$ \\
& Second & $42 \mathrm{~b}$ & $79 \mathrm{a}$ & $83 \mathrm{a}$ & $92 \mathrm{a}$ \\
& Third & $29 \mathrm{~b}$ & $79 \mathrm{a}$ & $83 \mathrm{a}$ & $88 \mathrm{a}$ \\
\hline
\end{tabular}

a,b Means in the same row, followed by the same letter, were not different $(P \leq 0.05)$ * Survival was different between fallow and sod in the first growing season $(P \leq 0.05)$

sizes within fallow, but differences were detected among sizes within sod, then the latter can be assumed to be a result of competition. Western wheatgrass competition reduced survival of blue grama seedlings in the 0 and 4-cm openings below that on fallow. A significant drop in blue grama survival (Table 2) occurred within 
Table 2. First growing season survival of blue grama seedlings planted 29 May 1985 into 4 sizes of opening in western wheatgrass sod.

\begin{tabular}{lcccc}
\hline \hline & \multicolumn{4}{c}{ Opening diameter, cm } \\
\cline { 2 - 5 } Date & 0 & 4 & 8 & 16 \\
\hline & $-\ldots$ & 100 & 96 & 100 \\
5 & 83 & 96 & 92 & 100 \\
13 June & $75^{*}$ & 83 & 88 & 92 \\
24 June & 54 & $79 *$ & 88 & 92 \\
5 July & 50 & 79 & 88 & 92 \\
12 July & 50 & 79 & 88 & 92 \\
22 July & 50 & 79 & 88 & 92 \\
26 July & 50 & 79 & 88 & 92 \\
2 August & 42 & 79 & 88 & 92 \\
9 August & 42 & 79 & 88 & 92 \\
16 August & 42 & 79 & 88 & 92 \\
26 August & 42 & & \\
\hline
\end{tabular}

*Survival first decreased significantly below $100 \%,(P<0.05)$

15 days of transplanting in the 0 -cm opening and within 37 days in the 4 -cm opening.

In all 3 years of the study, blue grama survival in sod (Table 1) was lower in the $0-\mathrm{cm}$ opening than in all other openings. A few additional plants died during the second and third years; most were in the $0-\mathrm{cm}$ opening.

Of the 96 plants in the fallow background, only 13 survived the first winter. The soil was free of snow cover during windy periods, which may have allowed dissiccation of the plants. The few remaining plants in fallow were not measured in the second and third growing seasons.

In the first growing season, blue grama plants averaged 13 seed heads per plant in fallow. Seed head number was reduced under all intensities of western wheatgrass competition and averaged 0.35 seed head per plant. Blue grama produces seed heads when adequate moisture is available (Dickinson and Dodd 1976). Competition from the western wheatgrass may have reduced the moisture level and therefore reduced seedhead production.

First year plant heights of blue grama (Table 3) averaged $50 \mathrm{~cm}$ in fallow. No significant differences occurred in response to soil

Table 3. Height at the end of the first growing season of blue grama seedlings planted into 4 sizes of openings in fallow soil or western wheatgrass sod.

\begin{tabular}{|c|c|c|c|c|}
\hline Planted in: & 0 & 4 & 8 & 16 \\
\hline & \multicolumn{4}{|c|}{$\ldots \ldots \ldots$ Extended height, $\mathrm{cm} \ldots \ldots \ldots$} \\
\hline Fallow & $\begin{array}{c}49 \text { a } \\
*\end{array}$ & $\begin{array}{c}52 \mathrm{a} \\
*\end{array}$ & $\underset{*}{51 \text { a }}$ & $\begin{array}{c}48 \text { a } \\
*\end{array}$ \\
\hline Sod & $15 \mathrm{c}$ & $21 \mathrm{bc}$ & $23 a b$ & $27 \mathrm{a}$ \\
\hline
\end{tabular}

a,b Means in the same row, followed by the same letter, were not different $(P \leq 0.05)$ ${ }^{*}$ Heights on fallow and sod are different $(P \leq 0.05)$

disturbance from coring. In sod, blue grama height increased with decreased intensity of competition. Plants were shorter in sod, averaging only $27 \mathrm{~cm}$ even within the largest openings.

After the third growing season, blue grama plants in the $16-\mathrm{cm}$ opening produced more above-ground phytomass than those in the 0 - and 4-cm openings (Fig. 1). Blue grama below-ground phytomass was higher in both the 8- and 16-cm openings than in 0 -and 4-cm openings, and higher in the $16-\mathrm{cm}$ than in the 8-cm openings. Competition may have been more intense below- than above-ground. Both above- and below-ground phytomass were positively related to opening size (Table 4 ), but below-ground phytomass was more closely correlated $\left(r^{2}=0.39\right)$ with opening size than was above-ground phytomass $\left(r^{2}=0.25\right)$. Obviously, blue grama phytomass will not increase indefinitely as opening size

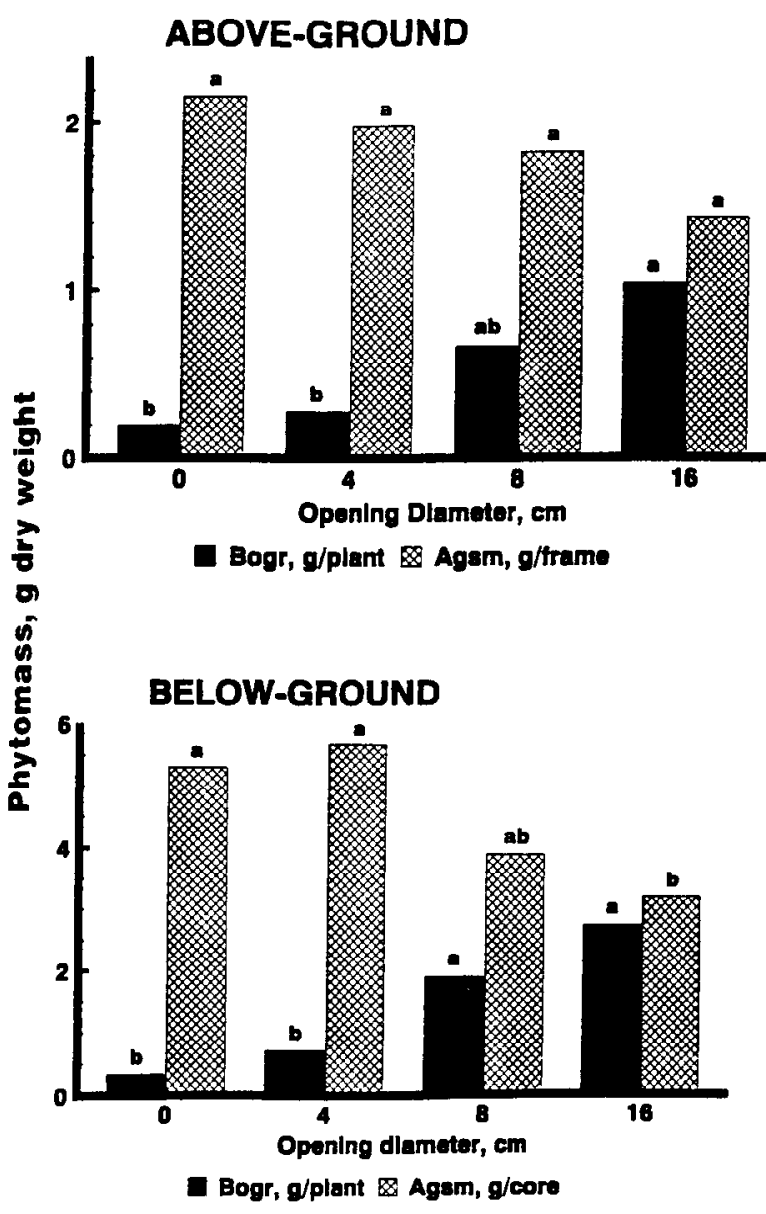

Fig. 1. Above- and below-ground phytomass of blue grama in western wheatgrass sod and of western wheatgrass at the end of the third growing season; phytomass weights within a species, labelled with the same letter, are not significantly different $(P<0.05)$.

increases. Aguilera (Range Science Department, Colorado State University, unpublished data) suggests near-maximum growth will be achieved in openings $30 \mathrm{~cm}$ or more in diameter.

Correlation was relatively low because variability of plant size increased with increasing opening size (Table 5). Standard errors of means in 0 - and 16-cm openings, respectively, were 0.05 and 0.19 for above-ground and 0.10 and 0.34 for below-ground phytomass. Weights of the smallest blue grama plants were similar in all opening sizes. For example, above-ground phytomass ranged from 0.03 to $0.38 \mathrm{~g} /$ plant in $0-\mathrm{cm}$ openings and from 0.03 to $2.79 \mathrm{~g}$ in 16-cm openings. Below-ground phytomass ranged from 0.09 to $0.85 \mathrm{~g} /$ plant in $0-\mathrm{cm}$ openings and from 0.17 to $5.46 \mathrm{~g}$ in $16-\mathrm{cm}$ openings. Reducing competition enabled the most vigorous blue grama seedlings to maximize their potential and grow much larger, but was of little benefit to less vigorous seedlings.

Table 4. Regressions of above- and below-ground phytomass $(B, g)$ of blue grama and western wheatgrass on opening size $(S, \mathrm{~cm})$ in sod.

\begin{tabular}{lcll}
\hline \hline Grass & $\begin{array}{c}\text { Above- or } \\
\text { below-ground }\end{array}$ & Equation & $r^{2}$ \\
\hline Blue grama & Above & $\mathrm{B}=0.14+0.0574 \mathrm{~S}$ & $0.25^{* *}$ \\
& Below & $\mathrm{B}=0.31+0.158 \mathrm{~S}$ & $0.39^{* *}$ \\
Western & Above & $\mathrm{B}=2.18-0.0464 \mathrm{~S}$ & $0.07^{*}$ \\
wheatgrass & Below & $\mathrm{B}=5.76-0.168 \mathrm{~S}$ & $0.27^{* *}$ \\
\hline
\end{tabular}


Table 5. Means, ranges, and standard errors of above- and below-ground phytomass of blue grama and western wheatgrass in and around 4 opening sizes in sod.

\begin{tabular}{|c|c|c|c|c|c|c|}
\hline \multirow[b]{2}{*}{ Grass } & \multirow{2}{*}{$\begin{array}{l}\text { Above- or } \\
\text { below-ground }\end{array}$} & \multirow[b]{2}{*}{ Parameter } & \multicolumn{4}{|c|}{ Opening size } \\
\hline & & & 0 & 4 & 8 & 16 \\
\hline Blue grama & Below & $\begin{array}{l}\text { Mean } \\
\text { Range } \\
\text { Std. error } \\
\text { Mean } \\
\text { Range } \\
\text { Std. error }\end{array}$ & $\begin{array}{l}0.20 \\
0.03-0.38 \\
0.05 \\
0.33 \\
0.09-0.85 \\
0.10\end{array}$ & $\begin{array}{l}0.28 \\
0.05-0.88 \\
0.05 \\
0.71 \\
0.26-1.62 \\
0.09\end{array}$ & $\begin{array}{l}0.67 \\
0.07-1.84 \\
0.11 \\
1.85 \\
0.54-4.14 \\
0.23\end{array}$ & $\begin{array}{l}1.04 \\
0.03-2.79 \\
0.19 \\
2.74 \\
0.17-5.46 \\
0.34\end{array}$ \\
\hline $\begin{array}{l}\text { Western } \\
\text { wheatgrass }\end{array}$ & $\begin{array}{l}\text { Above } \\
\text { Below }\end{array}$ & $\begin{array}{l}\text { Mean } \\
\text { Range } \\
\text { Std. error } \\
\text { Mean } \\
\text { Range } \\
\text { Std. error }\end{array}$ & $\begin{array}{l}2.17 \\
1.16-3.66 \\
0.27 \\
5.31 \\
4.18-6.48 \\
0.31\end{array}$ & $\begin{array}{l}1.99 \\
0.56-3.87 \\
0.26 \\
5.68 \\
1.02-8.30 \\
0.46\end{array}$ & $\begin{array}{l}1.83 \\
0.60-3.89 \\
0.21 \\
3.89 \\
1.74-6.54 \\
0.30\end{array}$ & $\begin{array}{l}1.39 \\
0.16-2.55 \\
0.16 \\
3.19 \\
0.91-5.20 \\
0.26\end{array}$ \\
\hline
\end{tabular}

Below-ground competition may have had greater effects than above-ground competition on western wheatgrass as well. Western wheatgrass above-ground phytomass in the sampling area of 16$\mathrm{cm}$ openings was less than that around smaller openings, with no differences among 0-, 4-, and 8-cm openings. But below-ground phytomass (roots and rhizomes) was less in the sampling area around both the 8 - and $16-\mathrm{cm}$ openings $\left(159 \mathrm{~g} \mathrm{~m}^{-2}\right)$ than around the 0 - and 4-cm openings $\left(273 \mathrm{~g} \mathrm{~m}^{-2}\right)$, with no difference between October 1987 and April 1988 harvests. Below-ground phytomass was more closely correlated with opening size $\left(r^{2}=0.27\right)$ than was above-ground phytomass $\left(r^{2}=0.07\right.$; Table 4).

Variability of phytomass of western wheatgrass decreased as phytomass decreased with increasing opening size (Table 5). Standard errors of means of above-ground phytomass were 0.27 and 0.16 in $0-$ and $16-\mathrm{cm}$ openings, respectively; corresponding figures for below-ground phytomass were 0.31 and 0.26 . Aboveground phytomass ranged from 1.16 to $3.66 \mathrm{~g}$ in $0-\mathrm{cm}$ openings and 0.16 to $2.55 \mathrm{~g}$ in $16-\mathrm{cm}$ openings. Below-ground phytomass ranged from 4.18 to $6.48 \mathrm{~g} /$ plant in $0-\mathrm{cm}$ openings and from 0.91 to $5.20 \mathrm{~g}$ in 16-cm openings.

Fewer western wheatgrass roots and rhizomes were able to re-establish in the larger openings, because more wheatgrass phytomass was removed and/or because blue grama established more vigorously in the larger openings and competed with the western wheatgrass for resources. Western wheatgrass rhizomes could easily have invaded all of the cored area; Mueller (1941) reported that during a year western wheatgrass rhizomes grew an average $132 \mathrm{~cm}$ in loamy soil and $25 \mathrm{~cm}$ in sand dunes. Competition was at least partly responsible for the reduction in wheatgrass below-ground phytomass in the larger openings. Competition may have had less effect on western wheatgrass above-ground phytomass because resources could have been transmitted through the rhizomes from roots outside the sampled area (Salzman and Parker 1985, Pitelka and Ashmun 1985).

Caldwell (1987) concluded that root competition often may be more intense than shoot competition under semiarid conditions. In semiarid short grasslands, intense grazing and low precipitation limit cover and reduce litter buildup, allowing light to reach the ground and reducing above-ground competition, but competition for water and nutrients continues below-ground (Barbour 1979, Belsky 1986).

The concept of 'neighborhood' may be useful in understanding the results of this study. Addicott et al. (1987) stated "We general- ize the concept of ecological neighborhoods to represent regions of activity or influence during periods of time appropriate to particular ecological processes. Therefore, there is no single ecological neighborhood for a given organism, but rather a number of neighborhoods, each appropriate to different processes."

All blue grama parameters measured responded to competition from western wheatgrass, but the patterns of response differed among parameters. Plant height and above- and below-ground phytomass increased steadily as opening size increased and competition decreased, but survival was reduced only in the 2 smallest openings. This may reflect timing. In the smallest opening, undisturbed western wheatgrass roots and rhizomes were immediately competitive with the blue grama transplants. In larger openings they became competitive only after they had reinvaded; by this time the transplants were so well established that competition did not reduce survival. Thus 'neighborhoods' may be temporal as well as spatial.

\section{Conclusions}

The impact of western wheatgrass competition on survival of blue grama seedlings was immediate, detectable within 15 days, and persistent, detectable at the end of the first growing season and after 3 growing seasons. The probability of survival and subsequent growth were dependent upon opening size and the resulting degree of competition in western wheatgrass sod. However, the effects of western wheatgrass were not entirely detrimental; few blue grama plants transplanted into fallow survived the first winter.

Blue grama establishment from seed requires that several favorable circumstances be present: (1) an adequate seed bank (Coffin and Lauenroth 1989, Peart 1989 a); (2) sufficient soil water at 2 separate time intervals for germination and for establishment of adventitious roots (Briske and Wilson 1978, Wilson and Briske 1979); and, as our study indicates, (3) levels of competition and protection which allow survival and growth of seedlings.

\section{Literature Cited}

Addicott, J.F., J.M. Aho, M.F. Antolin, D.K. Padilla, J.S. Richardson, and D.A. Soluk. 1987. Ecological neighborhoods: scaling environmental patterns. Oikos 49:340-346.

Barbour, M.G. 1979. Plant-plant interactions. p. 33-49. In: Goodall, D.W., R.A. Perry, and K.M.W. Howes. Arid-land ecosystems: structure, functioning and management, vol. 2. Cambridge Univ. Press, Cambridge, UK. 
Barkworth, M.E., and D.R. Dewey. 1985. Genomically based genera in the perennial Triticeae of North America: identification and membership. Amer. J. Bot. 72:767-776.

Bartos, D.L., and P.L. Sims. 1974. Root dynamics of a short-grass ecosystem. J. Range Manage. 27:33-36.

Belsky, A.J. 1986. Revegetation of artificial disturbances in grasslands of the Serengeti National Park, Tanzania. J. Ecol. 74:419-437.

Bement, R.E., D.F. Hervey, A.C. Everson, and L.O. Hylton, Jr. 1961. Use of asphalt-emulsion mulches to hasten grass-seedling establishment. J. Range Manage. 14:102-109.

Briske, D.D., and A.M. Wilson. 1978. Moisture and temperature requirements for adventitious root development in blue grama seedlings. J. Range Manage. 31:174-178.

Caldwell, M.M. 1987. Competition between root systems in natural communities. p. 167-185. In: P.J. Gregory, J.V. Lake, and D.A. Rose (eds.). Root Development and Function. Society for Experimental Biology Seminar Series 30. Cambridge Univ. Press, Cambridge, UK.

Coffin, D.P., and W.K. Lauenroth. 1988. The effects of disturbance size and frequency on a shortgrass plant community. Ecol. 69:1609-1617.

Coffin, D.P., and W.K. Lauenroth. 1989. Spatial and temporal variation in the seed bank of a semiarid grassland. Amer. J. Bot. 76:53 58.

Costello, D.F. 1944. Natural revegetation of abandoned plowed land in the mixed prairie association of northeastern Colorado. Ecol. 25:312-326.

Dickinson, C.E., and J.L. Dodd. 1976. Phenological pattern in the shortgrass prairie. Amer. Midl. Natur. 96:367-378.

Fenner, M. 1978. A comparison of the abilities of colonizers and closed-turf species to establish from seed in artificial swards. J. Ecol. 66:953-963.

Hyder, D.N., R.E. Bement, E.E. Remmenga, and D.F. Hervey. 1975. Ecological responses of native plants and guidelines for management of shortgrass range. USDA Tech. Bull. 1503.

Hyder, D.N., A.C. Everson, and R.E. Bement. 1971. Seedling morphology and seeding failures with blue grama. J. Range Manage. 24:287-292.

McConnaughay, K.D.M., and F.A. Bazzaz. 1987. The relationship between gap size and performance of several colonizing annuals. Ecol. 68:411-416.
Mueller, 1.M. 1941. An experimental study of rhizomes of certain prairie plants. Ecol. Monogr. 11:165-188.

National Oceanic and Atmospheric Administration (NOAA). 1986-1988. Climatological data, annual summary, Cheyenne, Wyoming. National Climatic Data Center, Asheville, N.C.

Peart, D.R. 1989a. Species interactions in a successional grassland. I. Seed rain and seedling recruitment. J. Ecol. 77:236-251.

Peart, D.R. 1989b. Species interactions in a successional grassland. II. Colonization of vegetated sites. J. Ecol. 77:252-266.

Peart, D.R. 1989c. Species interactions in a successional grassland. III. Effects of canopy gaps, gopher mounds and grazing on colonization. J. Ecol. 77:267-289.

Pitelka, L.F., and J.W. Ashmun. 1985. Physiology and integration of ramets in clonal plants. p. 399-435. In. J.B.C. Jackson, L.W. Buss, and R.E. Cook (eds.) Population biology and evolution of clonal organisms. Yale Univ. Press, New Haven, Conn.

Riegel, A. 1941. Life history and habits of blue grama. Trans. Kansas Acad. Sci. 44:76-83.

Salzman, A.G., and M.A. Parker. 1985. Neighbors ameliorate local salinity stress for a rhizomatous plant in a heterogenous environment. Oecologia 65:273-277.

Samuel, M.J. 1985. Growth parameter differences between populations of blue grama. J. Range Manage. 38:339-342.

Stevenson, A., R.E. Baumgartner, and G.E. Schuman. 1984. High Plains Grasslands Research Station-detailed soil survey. Univ. Wyoming Agr. Exp. Sta. Pub. 1-84/1C/3.62.

Tomanek, G.W., F.W. Albertson, and A. Riegel. 1955. Natural revegetation in a field abandoned for thirty-three years in central Kansas. Ecol. 36:407-412.

Weaver, J.E. 1958. Summary and interpretation of underground development in natural grassland communities. Ecol. Monogr. 28:55-78.

Weaver, J.E., and E. Zink. 1946. Annual increase of underground materials in three range grasses. Ecol. 27:115-127.

Wilson, A.M., and D.D. Briske. 1979. Seminal and adventitions root growth of blue grama seedlings on the Central Plains. J. Range Manage. 32:209-213.

\section{Associate Editor Nominations Journal of Range Management}

Replacements are needed for Associate Editors of the Journal of Range Management retiring from the Editorial Board in February, 1993. We are seeking nominees with expertise in: (1) animal physiology, animal ecology, plant/animal interactions and (2) improvements, plant physiology, plant ecology. Associate Editors serve for 2 years with an optional second term with the concurrence of the Editor, $J R M$. To nominate a candidate for this important and demanding position, ascertain that the individual is available and willing to serve and then send a letter of nomination to the Editor describing the nominee's qualifications. The candidate will be asked to supply a list of publications and an account of experience in reviewing manuscripts. Send nominations to: Gary Frasier, Editor, Journal of Range Management, 1300 Wheatridge Ct., Loveland, Colorado 80537 by 1 Oct. 1992. 